\title{
Innovative Way of Indonesian Muslim Millennial to Memorize the Qur'an: (Qur'an-Memo Community and the Making of Virtual Social Network)
}

\author{
$1^{\text {st }}$ Mohamad Sobirin ${ }^{1}$ \\ \{mohamadsobirin@,walisongo.ac.id $\left.{ }^{1}\right\}$ \\ Department of Qur'anic Studies UIN Walisongo Semarang ${ }^{1}$
}

\begin{abstract}
This study aims to answer important questions on the new phenomenon of memorizing the Qur'an practiced by Indonesian Muslim millennial who make use of android based application as tools to preserve the Qur'an i.e. Qur'an-Memo Community; can this app's features accede to their demand to memorize the Qur'an in the current context? And how do the app's methods of memorizing the Qur'an (tahfiz) guide them to learn by heart effectively? By applying a qualitative and descriptive-analytical approach, I found that the Qur'an-Memo Community seems to be able to fulfill the demand of Indonesian Muslim millennial to memorize the Qur'an in today's context. This app comes to innovate several aspects of the Qur'an memorizing tradition in Indonesia; (1) Integrating the tradition of memorizing the Qur'an with information technology, is the prominent reason to create this app to be compatible with "digital literate Muslims generation" who desire to commit the Qur'an into memory, (2) Method, this app offers new method of memorizing the Qur'an which called as linear method, recording, and puzzles, (3) Social networking, this app provides a service connecting all users which possibly would like give comments and corrections each other over their each own memorization (4) Corrections, in addition to services to provide feedback among fellow memorizers, there is also a corrective service guided by an ustaz who has mastered the Qur'an memorization in monthly paid mode. This correction service shows that although the way of memorizing the Qur'an seems new and innovative, it still holds the basic principle of the tradition of memorizing the Qur'an; the direct correction addressed by the experts of the Qur'an to users who perform the Qur'an memorizing.
\end{abstract}

Keywords: Qur'an-Memo Community; Memorizing the Qur'an (Tahfiz); Indonesian Muslim Millennial; Social Network.

\section{Introduction}

Memorizing the Qur'an is the practice of preserving the authenticity of God's most authentic revelation that Muslims have made since the Prophet's period to the present day. In the study of 
Qur'an (Ulumul Qur'an), the tradition of memorizing the holy book of Muslims is called tahfiz or hifz, and tahmil or hamalah. That is why a person who has memorized 30 Juz of the Qur'an given the title as al-hafiz or hamilul-Qur'an.

There are various methods to memorize the God's sound (kalamullah), which is pursued by Muslims. The methods have been being developed dynamically and varied throughout the lifetime following the demands of their contextual situation. It means that the methods undertook by Muslim communities in a particular place and time may not be the same as the methods carried out by other Muslim communities in culturally diverse circumstances. Among the existing methods for example; talaqqi, tasmi ',' arad, kitabah, tafhim, qira'ah fi as-shalah, self memorizing and memorizing per five verses in Indonesia [1]; Khatam 10, Chi method, Zor Pismis, Kolay Pismis, Tekrar, Tekrar Hepsi Seypa, Hasdan [2], Sabak method, Sabak, Ammokhtar and Halaqah Dauri [3] in Malaysia, and much more in some other countries. Each method has advantages and disadvantages. However, principally, all of the developed methods require the existence of an authoritative teacher (hafiz) who serves to provide corrections in case of mistakes of recitation on memorizing of a student during presenting his memorization of the Qur'an.

The emergence of these methods could be inasmuch as that Hifz is a complex, complicated, tough, and memory-based task. Hifz involves many memory enhanced practices. To memorize each and every word of Quran, exercises such as elaboration, visual imagery of the words, selfreferent encoding of the text of the Quran, sequencing, chunking, and mnemonic coding are in practice today [4].

In Indonesia today, along with the rapid development of the world of information technology, has been born a generation called millennial generation. Most of these generations have transitioned into the adult phase, and are graduated from college. Some have started careers or family building [5].

Demographically, they are a generation born from 1981 to 1999. Shelina Janmohamed [6] reveals the character of "Generation M" is belief and modern life, both as two things run in tandem without contradiction. They display the face of religion consistently but at the same time do not close themselves from the rapid progress of information technology. Their daily activities are always connected to the internet.

In order to answer the needs of this generation, an Android-based application developer in Indonesia launched a Quran application in September, 2017, which functioned as a tool to memorize Al-Qur'an combined with social network. This app is named "Qur'an-Memo Community" which can be installed via Play Store on Android-based gadgets. This application is attractive, due to its presence is warmly welcomed by Indonesian Muslim. This app has been downloaded by more than 50,000 times in one year.

\section{Research Question}

Therefore, this study is dedicated to uncovering; how does the experience of Indonesian Muslims millennial make use this application to memorize the Qur'an? Do this app's services and features work properly and effectively to guide users to memorizing the Qur'an? And, most importantly, what are the methods of memorizing the Qur'an offered through this application? is 
there any correction addressed to one's rote error? Also, is there an authoritative teacher (hafiz) who provides the correction? And how are the outputs and outcomes generated by this app?

\section{Literature Review}

Varoius academic literatures that have done the study which covers Qur'an memorization and Android based API is very rare, and so far I have found it in several journals merely as follows:

A Framework for Designing Mobile Quranic Memorization Tool Using Multimedia Interactive Learning Method For Children, in Journal of Theoretical and Applied Information Technology [7]. This article aims at providing a unifying framework for developing Quran memorizer application using multimedia interactive method and learning theories for mobile learning for children. It is quite different with my study which focuses on API to memorize the Qur'an in networked Muslim community in Indonesia.

Other recent notable work in the area of Quran studies on memorization using the cutting edge technology, e.g., "Pembangunan Aplikasi Bantu dalam Menghafal Al-Qur'an Berbasis Mobile [8] and "Aplikasi Pembelajaran Menyusun Ayat Sebagai Metode Menghafal Al-Qur'an (Juz 30)[9].

The first article proposed the application of Android-based applications to memorize AlQur'an with existing methods, which can read and listen to repeated (muraja'ah). While the second study, presents a design that has been tested in the manufacture of API to memorize the flashbased Qur'an that is destined to the students of "Rumah Qur'an-Nurul Hidayah". The method is not much different from the first article, e.g. muraja'ah. Muraja'ah has a meaning of listening activity to murattal that has been recorded in the application, and repeat or follow the reading. This is different from the methods carried by the Qur'an-Memo Community.

\section{Method}

To answer research questions, I employ qualitative approach and digital ethnography theory. While the exposure of this study I accommodate analytical descriptive approach. I apply this qualitative one over the object of this study which materially does not refer to a certain quantity. This approach will also be useful for outlining the app content that comprehend features and services comprehensively, as well as analyzing materials that imply the method of memorizing the Qur'an offered by this app to its users.

Then, I enable digital ethnography theory to be a tool in breaking aspects related to application services that present social network for the users. Applying digital ethnography, demographic data of users, e.g. age, sex and experience of memorizing the Qur'an accomodating this application will be described. 


\section{Result and Discussion}

A. Qur'an Memorization (Tahfidz al-Qur'an)

The phenomenon of memorizing al-Qur'an in the community is experiencing significant increase. This can be seen from the number of activities memorize al-Qur'an facilitated in tahfidz's home or activities tahfidz pesantren which has grown before. This phenomenon is not apart from the needs of the Muslims associated with the Qur'an memorizers felt more and more days, less and less. Indeed, memorizing al-Qur'an activities is not new.

However this activity has existed since the Prophet was still there and continued during the time of Khulafa' al-Rashidun until now. On that time, the Qur'an was not printed in a book form. Al-Qur'an is revealed by God by being written on leaves, stones, skin, or in a whisper directly by Angel Gabriel to the Prophet Muhammad. Because of this reason, people who can read the Qur'an mean those who can memorize the Qur'an properly and correctly.

During the Prophet's time, the memorization of the Qur'an was performed on a regular basis natural. That is, the Qur'an revealed by Allah through the angel Gabriel was then infused and understood by the Messenger of Allah until he himself memorized texts and their meanings and are then practiced. The Messenger of Allah then conveyed the revelation (Al-Qur'an) to his companions directly (mubasyarah) and teaches the verbal words (talaqqi).

Memorizing the Qur'an in Arabic term is Tahfidz Qur'an, it consists of two syllables, namely Tahfidz and the Qur'an, both of which have meaning different. namely tahfidz which means memorizing. Memorize from the memorized basic words from Arabic hafidza-yahfadzu-hifdzan, which is the opposite of forgetting, that is always remember and forget a little [10].

While according to Abdul Aziz Abdul Rauf the definition of memorize is "the process of repeating something good with read or hear." Any work if often repeated, must be memorized [11].

Someone who has memorized the Qur'an in a way overall out of the head, can be called juma' and huffazhul Qur'an. Collection of the Qur'an in a way memorizing (hifzhuhu) this was done in the early days of preaching Islamic religion, because the Qur'an at that time was revealed through the method of hearing. The preservation of the Qur'an through this memorization is very accurate and accountable, given that Rasulullah SAW belonged to the ummi, as illustrated by QS. Al-A'raf: 158 .

The Messenger loves the revelation, $\mathrm{He}$ always waiting for the decline of revelation with a sense of longing, then memorize and understand it, just as promised by God. Therefore, he is the first hafidz of the Qur'an and be the best model for the companions in memorizing it. Every time a verse had been revealed then it's memorized in the chest and placed in the heart, because of the Arabs naturally has a strong memorandum of understanding. It was due to they are generally illiterate, so deep writing stories, poems and their genealogies done with their heart note [12].

Imam Nawawi as a great scholar in Islamic studies has described various ethics in the study of Al-Qur'an discussed in his book At-Tibyan Fi Adabi Hamalatil Qur'an. Imam Nawawi said that the essence of the book begins in chapter IV which contains the ethics of teaching and learning the Al-Qur'an presenting very long discussion. As a hafidz, his thoughts which are contained in At-Tibyan conceptualized through his experience as the memorizer of Al- 
Qur'an. In general the concept the ethics of Imam Nawawi can be a concluded into two categories, namely personal ethics and social ethics of memorizer of the Qur'an.

Individual ethics talks about actions or behavior humans as individuals. In this case personal ethics explains about human obligations to themselves as participants learners in the learning process. In the activity of memorizing the Qur'an, there are several manners or ethics that need to be considered as a guide in behaving as students who have dependents for complete memorization of the Qur'an. There are three personal ethics noted Imam Nawawi's emphasis on the ethics of memorizing the Qur'an includes: concentration, purification of heart, commitment.

The social ethics has a meaning that in the process of communication and interaction with the environment surrounding both physical/psychological and social environment, people who memorize the Qur'an need guidance regarding how to act well. In the learning process, he does not only involve himself but is also involved with other people in the learning environment. In this case, Imam Nawawi formulated several social ethics in learning (memorizing the Qur'an) into three parts, namely: obligation to teachers, obligations to learning friends, and obligations towards literature.

\section{B. Qur'an-Memo Community: Accessing Features}

This study observes and examines the most popular and downloaded application of Qur'an for memorization in Indonesia, i.e. Qur'an-Memo Community. Even there are actually more than this application in the App Store of Android devise system. The big number of downloader and user of this application becomes a certain consideration for me. In this section I will outline and describe this application for the provided features, how to operate and run it, and designed display. I will proceed by capturing screen so as to make it design imaginable and this research easier to digest by readers and become obvious.

Qur'an-Memo Community is an application developed by UBK Plus ${ }^{1}$ which can be operate and access after creating an account by filling in queries contain information that shows name and identity accompanied by email used as username account. This APK is different from the number of APKs, as it requires the complete identity of the account of user. So the accuracy of user's identity represents his or her factual identity.

After the registration has succeeded, user can access this application by $\log$ in. Successful log in will bring user to access available features. These are based on menus appear include (1) Memorizing (Menghafal), (2) Reading (Membaca), and (3) Learning the Qur'an (Belajar AlQur'an). But the first and second menu seems to be the most frequently accessed by the user among the three, due to user's purpose of downloading this APK is none other than to memorize the Qur'an and read it, and in addition, because the feature of "Learning the Qur'an (Belajar AlQur'an)" which contains makhraj, tahsin, and murattal, is only provided on a paid mode.

Every user of this APK can enjoy the general features provided free of charge and features with special facilities that can only be enjoyed by paying. General features that can be accessed freely ranging from the new memorization that users want to do, the list of memorized users (not memorized and already memorized), users who need correction, and digital manuscripts of the

\footnotetext{
${ }^{1}$ This developer is located at Mutiara Jingga Residen No.3, Pondok Cabe Ilir Tangerang Selatan Banten.
} 
Qur'an that gives the option to display only Arabic text or its translations for reading purposes (there is a last page marker read) and memorized. This free feature has facilities restrictions; $1 \mathrm{x}$ save recording, $3 \times$ save memorize, tafsir only Juz 30, memorize only Juz 30 and Al-Fatihah, and murattal only from Sheikh Alfasy.

While the application is designed for the purposes of reading and memorizing the Qur'an, it also provides the feature to share the activities of memorizing via social media.

Paid mode of this app provides 3 kinds of packages; (1) Package of Islam (10.000 per month), (2) Package of Iman (20,000 per month), and (3) Package of Ihsan (50,000 per month). This mode serves the same features as free of charge mode, but users can enjoy additional distinctive facilities. For example, it can save the recording of memorization from 10 times to unlimited, listen to all murattal of all Qari', memorize all Juz, learn all the tafsir of $30 \mathrm{Juz}$, access the content of learning the Qur'an e.g. makhraj and tahsin, and the most significant facility is the intensive correction facilities toward memorization, murattal and tajwid by ustaz who are directed by APK. Unfortunately, it is only for package of Ihsan.

\section{Millennial Muslim's Methods to Memorize the Qur'an}

There are three methods of memorizing the Qur'an built into this application system. Each method has a functional interconnectedness that mutually support each other in directing user activity while memorizing the Qur'an, i.e.;

1. Linier, which consists of several stages of the process of memorization:

a. Memorizing verses of the Qur'an and its translations. In this first model, user is allowed to listen to Qari's reading provided by the API by clicking on the "play" icon. There is a counter icon of how many times the user has listened to the recording. Similarly, the user can also count the number of times he has read the verses he memorized and the translations. Therefore, the Arabic text of the verses of the Qur'an is accompanied by a translation. Apparently, this API wants to direct the user to repeat in listening to Qari's recitals of the Qur'an recitations and to read the Qur'an verses which are printed by imitating the Qari's reading as in the available recording. This model is actually often done by many Muslims today in memorizing the Qur'an independently. This model includes the activity of listening and reading in adventurous or known as muraja'ah.

b. Memorizing the Arabic text of the verses of the Qur'an. In this second model, the provided features are equal to the first model except the removal of the translated text display. This is so that the user can focus only on memorizing Arabic texts from the verses of the Qur'an, in contrast to the first model that recommends the user to not merely memorize Arabic verses of the Qur'an, but also the translation.

c. Memorizing the translation of the Qur'an verses and studying its tafsir (commentary). Therefore, the displayed text is only translation of the verses of the Qur'an without Arabic text of the Qur'an verses. In addition, the interpretation of the verse is also displayed by clicking on the commentary icon. The interpretation is expressed in Indonesian. When I carefully observed, the commentary may be included as ijmali (general commentary), since the description given tends to be as simple as the definition of interpretation of ijmali. Yet, the source or reference of its commentary is not mentioned whether it is copied or quoted from a certain book or mufassir. This lack should be fixed because it is very fundamental academically. 
2. Recording, it is the second method done by reading every omitted word. The omitted word sometimes is on the beginning of the verse, the end, the middle, the beginning and the end, and the random. When user has perfectly memorized, he/she can begin recording for rote tests, then the recording will be corrected by another user or ustaz of the Qur'anMemo. This recording method seems eager to improve the rote generated after the first method (linear). Because user possibly know the smoothness and precision of memorization by recording it, and corrected by professional corrector i.e. ustaz (hafiz). At this stage, this digital memorizing tradition retains the tradition of memorizing the Qur'an in Indonesia, where social network built through memorizing the Qur'an in the Javanese context which is known as "sema'an" has been successfully transformed into digital based social network. The tradition of "sema'an" as a practice of reciting the Qur'an bil ghaib (without reading the text of mushaf) done by user of the Qur'an is played by other user with the intention of launching rote and obtaining correction. This social interaction process digitally is element forms the social network among the memorizers.

3. Puzzle, this method is intended to test the quality of memorized verses through the process of randomizing the sequence of words forming a verse from a particular letter (surat), then user is asked to match the missing target words in sequence.

\section{The Making of Virtual Social Networking Through Online Qur'an Memorization}

This app which is released on September 19, 2017, can be considered as a tool to memorize Al-Quran that combining the method of self-memorization with social networks. Because, it connects the memorizers of the Qur'an one another, where they are given an opportunity to interact and give feedback to each other among themselves regarding their own memorizing. The tagline displayed by this APK "The Assembly Memorizing the Qur'an" also describes the function of this APK which is not merely to memorize the Qur'an but also as a container for the interaction of the Qur'an memorizers digitally. This can be reviewed in the feature which shows comment field that can be filled with an input either suggestions or corrections to other APK users who want get correction. The user's identity is also seen in this service. For example, the user named as Muhammad Suthon Alfatih can be observed as someone who get 2 corrections from fellow users of this APK, which is specifically marked with red in 2 words. In the meantime, notes containing comments and suggestions provided are only visible to accounts that receive such comments and suggestions privately.

\section{E. Digital Observation on User's Demographic, Digital Activities, and Experiences}

I did a digital observation by a community approach that could represent the demographics of users of this APK which I assume are young religious Muslim. My digital observations on user's identity generated some points describing any answers of the above research questions, i.e. These APK user's age is ranging from 15 years old to 35 , this is based on majority population view, and they are male and female. The youngest is such as Siti Hanima (15, F), while the oldest is Dody Yuwanto $(35, \mathrm{M})$.

Those who are in the range between 15 and 35 years old are as Fadilah Ramadani (16, F), Andini Fathur Robby (17, F), Aditya Nugraha (18, M), Dita Silviani (20, F), Hijrawati Herman Umar (22, F), Ahmad Alqodri (23, M), Syahnaz Ulfa Nurzanah (24, F), Ahmad (25, M) and Erwin 
Sutisna (28 old, M), Saharul Nizam (29 old) , M), Novita Arisandi (30, F), Muhammad Sulthon Alfatih (31, M).

As users, they are given the option to upload an avatar in a jpeg photo formatted as an icon on its account. Only, not many who take advantage of this service. The vast majority of them do not use a picture of themselves, but only standard avatars. So it becomes difficult to accurately recognize the people behind a particular account exactly. Because, someone may be have a similar names with another that make difficulty to recognize each of them. In my opinion, this aspect indicates the inconsistency of this APK in carrying the vision to be an app for community-based Qur'an memorizing

Nevertheless, this APK still shows its efforts to facilitate the making of social interaction among the memorizers of the Qur'an thoroughly, although they will still have difficulty recognizing accurately one another's identity. The social network that can be built between the users, at least is that they can see an update memorization activities performed by each of them, and they can say hello to each other while giving comments either suggestions or corrections to this APK fellow users. Because this APK displays 3 online activities of all users; (1) who are memorizing (displaying user names, letters and verses being memorized, age of user along with profile photo, and when last online to memorize), (2) who already memorized (same with the first activity, but in this activity show the letter and verse that has been mastered through memorize), (3) need correction, this activity indicates reading other user who want to get correction from APK fellow user. The number of comments that have been shared and on what part of the correction is given may also be reviewed directly by clicking on the posted account in this part of activity.

\section{F. Indonesian Millennial Muslim and the Survey toward Qur'an-Memo Users}

The report results of a recent study noted that internet users in Indonesia reached 82 million. The figure is of course very fantastic and become soggy fields to spread the ideas of all kinds. The issue becomes so complex because 80 percent of that number is from the children and adolescents in the age range 15-19 years. The data is the result of a study entitled "Digital Citizenship Safety Among Children and Adolescents in Indonesia" which made the UN agency for children, UNICEF, with its partners, including the Ministry of Communications and Information Technology and Harvard University, USA(https://kominfo.go.id).

While the other results of a survey conducted by Indonesian Internet Service Provider Association in 2015 stated that the number of internet users in Indonesia in 2014 as many as 88.1 million people or 34.9 percent of the total population of Indonesia. This figure also implies an increase in the public internet use from the previous year. The survey results also suggested by category of age 49 percent of internet users in Indonesia is dominated by the younger generation aged 18-25 years old.

The fact surely indicates positive developments of the young generation of this nation to follow the dynamics of such modern world. With a large percentage of young people who access the Internet, certainly more wide open the potential for the spread of any ideas to them and change their tradition of being human as citizen in real to be netizen in digital or new media world (http://tekno.kompas.com).

Considering the above total percentage of internet users report, and relates it with Qur'anMemo application could actually result in a conclusion that the real users of digital Qur'an applications more dominated by the user from young people where are no more than 40 years old. 
As for the old man tend to be restricted to those who are still in contact with the internet for job so in very small number. There are many factors why it could be happening, for example, the skill to use a smart phone or internet devices is quite complicated to them.

Therefore, young people are those who engage and colour the discourse and content of digital world, whether as user or designer of the Apps, including Qur'an-Memo. They are a new generation of so-called digital generation in which if associated with a digital Qur'an they could be termed as "digitally literate Muslims generation".

In this section, I report the result of my survey toward a community which makes a use of this digital Qur'an-Memo. This community is student of Qur'anic studies department at State Islamic University (UIN) Walisongo Semarang. They represent the most active of internet users in Indonesia who are relevant to this application, among Indonesian millennial that reached $82.8 \%$ of wholly internet users. I did a way of this survey by purposive sample of 100 students. This survey aims to discover their satisfaction as users of this application. $73 \%$ of them are satisfied to use this application to memorize the Qur'an, even though $89 \%$ of this percentage stated that they would only use this app as a complement tool when practicing Qur'an memorizing, the main way of their own memorizing activities are decided in traditional way of memorizing Qur'an such as by accessing printed mushafand delivering the memorized verses to their teachers. Then, the rest stated that they don't need to memorize the Qur'an in traditional mode, they feel enough by using this application. So, there are merely $27 \%$ of purposive sampling who stated are not satisfied enough to use this application due to theological reason i.e. the lack of barakah, and technical reason such as it is its compatibility to their situation.

Then, reviewing this APK's page on Google Play, I see various comments stated by this app's users. Their comments reflect how they feel the experience in using this APK. Their responds are very varied, ranging from simply praising the presence of this APK to expressing criticism and advice for this APK, for instance, to give "separator" between male and female users to avoid possibility of their misusing to this APK to do dating, and to provide an open access to view any corrections which are addressed to any users. Similarly there are those who deliver questions and complaints because they still do not understand well how to take advantage of this APK features perfectly and how to run it technically.

In my view, after observing comprehensively the APK and the responses of users who are representing the Indonesian Muslim millennial, this App is generally able to fulfill the needs of Indonesian Muslim millennial to do interaction with the Qur'an in the way of memorizing. Because it also provides features to memorize, it also provides a feature to read and understand the meaning of the Qur'an through its translation and commentary in Indonesian. It is in accordance with statement of Tahraoui Ramdane and Merah Souad "Muslims regarded the forms of interaction with the Qur'an by way of recitation, memorization, analysis and interpretation as a key part and prerequisite for learning and spiritual salvation"'[13].

\section{Conclusions}

This study remarks that Qur'an-Memo Community App is able to accede to the demands of Indonesian Muslim millennial in memorizing the Qur'an. They can memorize the Qur'an without having to enter a class, living in a boarding school (pondok pesantren), meet with the teacher 
(setoran hafalan or ngaji), and hold the mushaf printed by publisher of the Qur'an. They as this app's users can memorize the Qur'an while doing other activities. In my view, it becomes the challenge for them to be able to complete memorizing $30 \mathrm{Juz}$ of the Qur'an. Because, they must carefully manage their own schedule to memorize independently. It could be the reason why no user has been announced, graduated, and certified yet, has completed (khatam) memorizing $30 \mathrm{Juz}$ of the Qur'an.

\section{References}

[1] F. Wajdi, "Tahfiz Al-Qur'an dalam Kajian Ulum Al-Qur'an (Studi atas Berbagai Metode Tahfiz)," UIN Syarif Hidayatullah., 2008.

[2] S. Ariffin, M. Abdullah, and K. Ahmad, "Method on Memorization the Quran in Malaysia: A Study in Darul Tuba Institute, Malaysia," in Proceedings of the International Conference on Global Business, Economics, Finance and Social Sciences, 2015, pp. 1-9.

[3] S. Ariffin et al., "Effective Techniques of Memorizing the Quran: A Study at Madrasah tahfiz Alquran, Terengganu, Malaysia," Middle-East J. Sci. Res., vol. 13, no. 1, pp. 45-48, 2013.

[4] N. Nawaz and P. D. S. F. Jahangir, "Effects of Memorizing Quran by Heart (Hifz) On Later Academic Achievement," J. Islam. Stud. Cult., vol. 3, no. 1, 2015.

[5] P. Werbner, "The Predicament of Diaspora and Millennial Islam," Ethnicities, vol. 4, no. 4, pp. 451-476, Dec. 2004.

[6] S. Janmohamed, Generation M: Young Muslims Changing the World. London and New York: I.B.Tauris and Co.Ltd., 2016.

[7] S. N. W. Shamsuddin et al., "A Framework for Designing Mobile Quranic Memorization Tool Using Multimedia Interactive Learning Method For Children,” J. Theor. Appl. Inf. Technol., vol. 92, no. 1, pp. 20-27, 2016.

[8] M. Y. Herdiansyah and I. Afrianto, "Pembangunan Aplikasi Bantu dalam Menghafal Al-Qur'an Berbasis Mobile," J. Ilm. Komput. dan Inform., vol. 2, no. 2, pp. 1-8, 2013.

[9] L. Norhan and L. Sanjaya, “Aplikasi Pembelajaran Menyusun Ayat Sebagai Metode Menghafal AlQur'an (Juz 30),” J. Online Inform., vol. 1, no. 2, pp. 87-91, Dec. 2016.

[10] M. Ikhwanuddin, "Relationship Between Memorization Technique, Mastery of The Arabic Language and Understanding of The Qur'an," Tasyri, vol. 24, no. 1, pp. 1-13, 2007

[11] A. R. A. Aziz, Kiat Sukses Menjadi Hafizh Qur'ān Da 'iyah. Bandung: Syamil Cipta Media, 2004.

[12] M. K. Al-Qattan, Mabahits fi Ulumil Qur'an. Beirut: Darul Kutub, 2012.

[13] T. Ramdane and M. Souad, "Towards a New Approach in the Teaching of the Holy Qur'an," Int. J. Humanit. Soc. Sci., vol. 7, no. 10, pp. 143-152, 2017. 